\title{
Risk factor control in hypertensive and diabetic subjects attended by the Family Health Strategy in the State of Pernambuco, Brazil: the SERVIDIAH Study
}

\section{Controle dos fatores de risco em hipertensos e diabéticos acompanhados pela Estratégia Saúde da Família no Estado de Pernambuco, Brasil: Estudo SERVIDIAH}

Control de los factores de riesgo en hipertensos y diabéticos seguidos por la Estrategia Salud de la Familia en el estado de Pernambuco, Brasil: estudio SERVIDIAH
Annick Fontbonne 1

Eduarda Ângela Pessoa Cesse 2

Islândia Maria Carvalho de Sousa 2 Wayner Vieira de Souza 2

Vera Lúcia de Vasconcelos Chaves 2 Adriana Falangola Benjamin Bezerra 3 Eduardo Freese de Carvalho 2
1 UMR 204 Nutripass, Institut de Recherche pour le Développement, Montpellier, France.

2 Centro de Pesquisas Aggeu Magalhães, Fundação Oswaldo Cruz, Recife, Brasil. 3 Centro de Ciências da Saúde, Universidade Federa de Pernambuco, Recife, Brasil.

Correspondence E. A. P. Cesse

Departamento de Saúde Coletiva, Centro de Pesquisa Aggeu Magalhães, Fundação Oswaldo Cruz.

Av. Moraes Rego s/n, Recife, PE 50670-420, Brasil.

educesse@cpqam.fiocruz.br

\section{Abstract}

The SERVIDIAH study (Evaluation of Health Services for Diabetic and Hypertensive Subjects) was conducted in 2010 in the State of Pernambuco, Brazil. A multi-stage random sample of 785 hypertensive and 823 diabetic patients was drawn from 208 Family Health Strategy (FHS) units selected throughout 35 municipalities. Patients underwent a structured interview and weight, height, blood pressure and HbAlc levels (for diabetic patients) were measured. Mean age was approximately 60 years, and women were overrepresented in the sample (70\%). $43.7 \%$ of hypertensive subjects and $25.8 \%$ of diabetic subjects achieved adequate blood pressure control and 30.5\% of diabetic subjects had HbAlc levels below 7\%. Despite 70\% of the patients being overweight or obese, few had adhered to a weight-loss diet. The study of this representative sample of hypertensive and diabetic patients attended by the FHS in the State of Pernambuco shows that improvements in the management of hypertension and diabetes are needed in order to prevent the occurrence of serious and costly complications, especially given the context of increasing incidence of these two conditions.

Hypertension; Diabetes Mellitus; Family Health Program; Risk Factors

\section{Resumo}

O estudo SERVIDIAH (Avaliação de Serviços de Atenção Básica à Saúde para Diabéticos e Hipertensos) foi realizado em 2010 no Estado de Pernambuco, Brasil. Foi constituída uma amostra aleatória de 785 hipertensos e 823 diabéticos oriunda dos cadastros de 208 equipes da Estratégia Saúde da Família (ESF) sorteadas em 35 municípios do estado. Os usuários foram entrevistados por meio de formulário padronizado, e tiveram aferição de peso, altura e pressão arterial e, para os diabéticos, da hemoglobina glicada (HbAlc). A idade média foi em torno de 60 anos, com sobrerrepresentação de mulheres (70\%). A pressão arterial foi controlada em 43,7\% dos hipertensos e 25,8\% dos diabéticos; 30,5\% dos diabéticos apresentaram HbAlc abaixo de 7\%. Apesar de 70\% apresentarem sobrepeso ou obesidade, poucos referiram estar seguindo dieta para perder peso. O estudo, nesta amostra representativa de hipertensos e diabéticos cadastrados na ESF de Pernambuco, mostra que melhorias devem ser buscadas a fim de aprimorar a prevenção das complicações desses agravos, cuja incidência está crescente.

Hipertensão; Diabetes Mellitus; Programa Saúde da Família; Fatores de Risco 


\section{Introduction}

The rapid increase in prevalence of common nutrition-related chronic diseases, such as arterial hypertension and type 2 diabetes, is a worldwide phenomenon and poses one of the major challenges to public health in the 21st century 1 . The diagnosis of these diseases is often delayed due to lack of symptoms and the resulting complications are costly for the patient, in terms of health and quality of life, and for society 2 . The prevention of these complications requires early diagnosis and interventions that favorably influence prognosis, as well as regular monitoring to control blood pressure, blood glucose levels and other cardiovascular risk factors 3,4 . The systematic, long-term surveillance of patients with chronic illnesses to avoid later life-threatening or incapacitating conditions is not symptom-driven and represents a shift in approach for most health care systems that were originally organized to react to acute illnesses by diagnosing the problem, initiating treatment and dismissing the patient until another acute episode requires renewed medical attention 5,6.

In 2001, the Brazilian Ministry of Health launched a plan to improve primary care for hypertensive and diabetic individuals which focuses on three key areas: continuous professional education, promotion of healthy lifestyle habits and registration of hypertensive and diabetic patients in primary care units 7 . Primary care in Brazil, particularly in the North-east Region, is increasingly provided through the Family Health Strategy (FHS). A FHS team comprises of at least one physician, one nurse, one nurse technician and a lay Community Health Worker (CHW), and is responsible for the primary care of the population of a specific geographical area. This strategy has been shown to have a positive impact on various health and social indicators 8,9. However, to date, few studies have assessed the implementation and real results of the plan to improve primary care for hypertensive and diabetic individuals within the FHS. This was the main aim of the SERVIDIAH study (Evaluation of Health Services for Diabetic and Hypertensive Subjects), conducted between 2009 and 2010 which analyzed a representative sample of hypertensive and diabetic individuals registered in the FHS in the State of Pernambuco, Brazil.

One of the objectives of the plan to improve primary care for hypertensive and diabetic subjects is to achieve control of hypertension and diabetes and other cardiovascular risk factors to prevent potential future complications. The objective of the present analysis of the SERVIDIAH database was to describe and compare the de- gree of control of these disorders among subjects attended by the FHS in the State of Pernambuco by municipality size.

\section{Methodology}

The SERVIDIAH study is an epidemiological survey of a representative sample of patients with hypertension or type 2 diabetes registered with FHS units in the State of Pernambuco conducted between November 2009 and December 2010. The study covered 35 municipalities (Figure 1), of which 16 were small (less than 20,000 inhabitants), 16 were medium-sized (between 20,000 and 100,000 inhabitants), and three were large (over 100,000 inhabitants). The small and medium-sized municipalities were randomly selected from the 2000 Brazilian census using the random command of Epi Info software (Centers for Disease Control and Prevention, Atlanta, USA), while the three large municipalities (Recife, Caruaru and Petrolina) were chosen because they are the capital cities of the three macroregions of the State of Pernambuco (Zona da Mata, Agreste, Sertão). One out of ten FHS units were randomly selected from the FSH units listed in August 2008 on the National Register of Health Establishments (CNES), the most recently consolidated database available at the time of study design.

\section{Selection of subjects}

One CHW from each selected FHS unit (a total of 37 in small municipalities, 98 in medium-sized municipalities and 73 in large municipalities) was selected to participate in the study. Subjects were randomly selected from the patient list compiled by each CHW since this record is considered the most accurate and up to date patient registry. The following numbers of hypertensive and diabetic subjects over 20 years of age were selected from these lists: small municipalities (six hypertensive and six diabetic subjects); medium-sized municipalities (three hypertensive and three diabetic subjects); large municipalities (four hypertensive and four diabetic subjects). The aim was to ensure an even balance of around 300 subjects in each municipality size category, allowing a $10 \%$ difference in control between municipality size, with a statistical power of $80 \%$ and a $5 \%$ significance level.

Subjects registered by the CHW as having arterial hypertension but not diabetes were considered hypertensive and those registered as having type 2 diabetes were considered diabetic, regardless of the presence or absence of associated arterial hypertension. Sample members were select- 


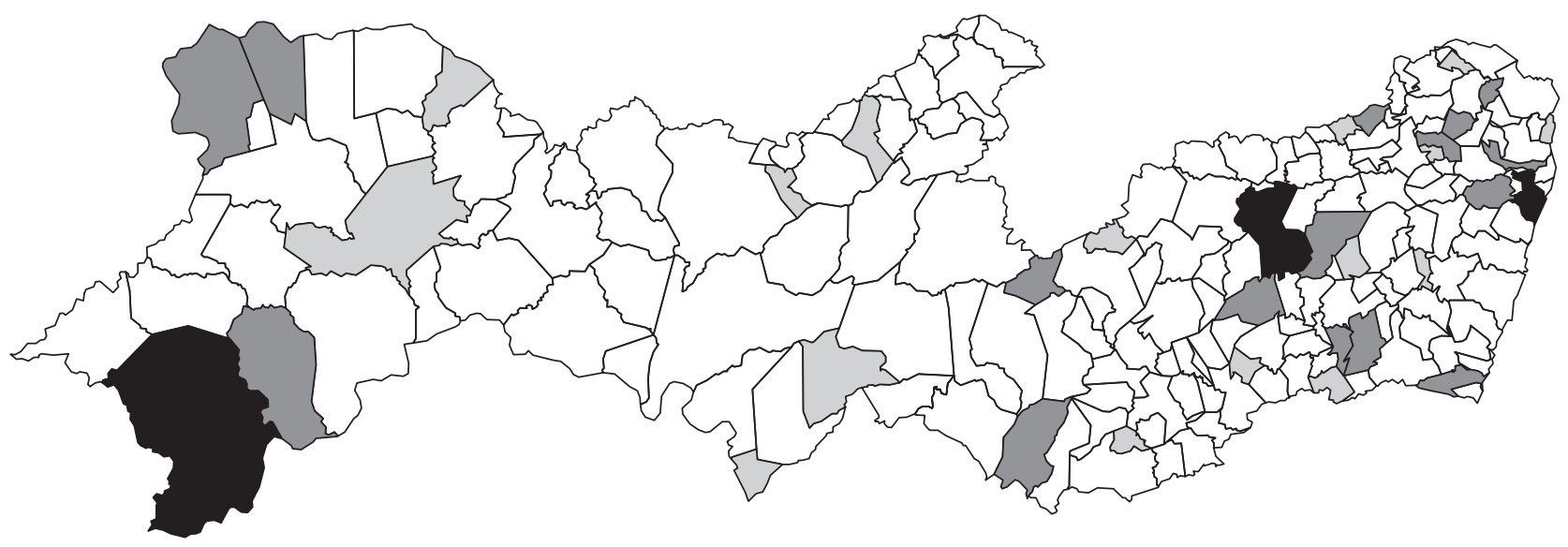

$\square$ Small
Medium
Large
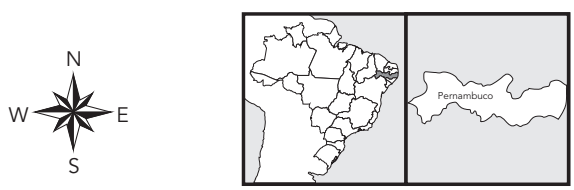

ed randomly from the list until the desired final number of hypertensive and diabetic subjects for each FHS unit was obtained. All efforts were made to include all designated subjects. Those subjects that were unable to participate in an interview at the FHS unit itself, or some local public facility nearby or on a weekday, were interviewed at home or at the workplace or on weekends. In order to maintain representativeness, subjects were not substituted when it was not possible to interview the individual. The general response rate was $86.7 \%$.

The study was approved by the Ethics Committee of the Aggeu Magalhães Research Centre, Oswaldo Cruz Foundation (CPqAM/Fiocruz) and the Brazilian National Commission of Ethics in Research (CONEP). All participating subjects were duly informed of the objectives and procedures of the study, and all signed an informed consent form.

\section{Data collection}

Data was collected using a structured questionnaire and face-to-face interviews conducted by trained investigators. Information was gathered about demographic and socio-economic characteristics, physical activity (no/yes), tobacco consumption, adhesion to salt-free, sugar-free, and/ or weight-loss diets, hypertension or diabetes care received at the FHS unit, type of treatment and clinical control of hypertension or diabetes and of other cardiovascular risk factors, as well as satisfaction with the care received and potential expenses related to health care.

Systolic and diastolic blood pressures were measured to the nearest $\mathrm{mmHg}$ at the left wrist three times during the interview, with the subject seated for at least 10 minutes prior to measurement. The mean of the three values was used for the analysis. Blood pressure was considered well controlled if mean systolic and mean diastolic blood pressure were below $140 \mathrm{mmHg}$ and $90 \mathrm{mmHg}$, respectively, in hypertensive subjects, and below $130 \mathrm{mmHg}$ and $80 \mathrm{mmHg}$, respectively, in diabetic subjects 3 .

Glycemic control was assessed by measuring HbAlc levels from a capillary blood sample using the in2it point-of-care analyzer (Bio-Rad Laboratories Inc., Berkeley, USA). In accordance with 
the recommendations of the American Diabetes Association ${ }^{4}$, diabetes was considered as well controlled if $\mathrm{HbAlc}$ was below $7 \%$.

Study subjects were weighed wearing light clothing using a Tanita BC553 electronic scale (Tanita Corp., Tokyo, Japan), which is accurate to the nearest $0.1 \mathrm{~kg}$, while height was measured using a portable stadiometer (Alturaexata, Belo Horizonte, Brazil), which is accurate to the nearest mm. Body mass index (BMI) was calculated based on weight divided by squared height $(\mathrm{kg} /$ $\mathrm{m}^{2}$ ). Subjects with a BMI between 25 and 29.9 were considered overweight and subjects with a BMI equal to greater than 30 were classified as obese (World Health Organization criteria) 10.

\section{Statistical analysis}

Hypertensive and diabetic subjects were grouped into independent samples and analyzed separately. Continuous variables are expressed as mean \pm standard deviation (SD), while categorical variables are presented as percentages. Comparisons by municipality size and by category of blood pressure or glycemic control were performed using standard parametric tests (ANOVA for continuous variables and chi-square for categorical variables).

Since the sampling procedure gave equal weighting to municipalities regardless of size, crude means and percentages of the total sample were corrected to make them representative of the whole state. The distribution of hypertensive and diabetic subjects from the SERVIDIAH sample in small, medium-sized and large municipalities was $25.3 \%, 36.3 \%$ and $38.4 \%$, respectively. The distribution of FHS registered hypertensive and diabetic subjects in small, mediumsized and large municipalities in the state of Pernambuco, reported on the website of the Brazilian Ministry of Health in December 2009, was $16.9 \%, 43.6 \%$ and $39.5 \%$, respectively. The correction coefficients were calculated by dividing the municipality size percentage given for the entire State of Pernambuco by the relevant percentage given by the SERVIDIAH sample, resulting in the following values: $0.169 / 0.253=0.668$ for small municipalities, $0.436 / 0.363=1.201$ for medium-sized municipalities, and 0.395/0.384 = 1.029 for large municipalities. These coefficients were used to calculate the means and percentages of the entire state using the "weight" command of the SPSS statistics module (SPSS Inc. Chicago, USA).

All statistical analyses were performed using SPSS version 19

\section{Results}

A total of 785 hypertensive and 823 diabetic subjects were interviewed throughout the 35 municipalities included in the SERVIDIAH study. Mean age was around 60 years in the two samples, and women represented more than two-thirds of the sample. Almost $40 \%$ of the sample had no formal schooling and received an income below the minimum wage ( $\mathrm{R} \$ 545$ at the time of the study, equivalent to approximately US\$310) (Table 1). Most subjects had no formal employment, 942 were retired or had a pension, and 294 were housewives or students. The following statistical differences between the municipalities of different sizes were found: the education level of both hypertensive and diabetic subjects was highest in large municipalities and lowest in small municipalities; the proportion of diabetic subjects that reported receiving an income below minimum wage was greater in large municipalities; the proportion of hypertensive subjects with no formal employment was lowest in large municipalities.

The clinical characteristics of the diseases are shown in Table 2. For both hypertensive and diabetic subjects, the known duration of disease was around nine years. Over $90 \%$ of subjects were using some form of pharmacological treatment for the disease; the proportion of hypertensive subjects using some form of pharmacological treatment was significantly greater in large municipalities, and significantly smaller in small municipalities. Insulin treatment, alone or in combination, was used by $15.6 \%$ of the diabetic subjects. Adherence to a low-salt diet among hypertensive subjects and diabetic subjects with hypertension was high $(88.1 \%)$ and adherence rates increased with decreasing municipality size. Adherence to a low-sugar diet in diabetic subjects was also high (87.3\%), and adherence rates also increased with decreasing municipality size. On the other hand, the adherence rate for weight-loss diets was low (16.1\% in hypertensive subjects and $13.6 \%$ among diabetic subjects). Adherence to weightloss diets among diabetic subjects appeared to be greater in large municipalities.

With regard to the control of cardiometabolic risk factors, Table 3 shows that blood pressure was below $140 / 90 \mathrm{mmHg}$ in $43.7 \%$ of the hypertensive subjects, and over the recommended threshold of $130 / 80 \mathrm{mmHg}$ in $74.2 \%$ of the diabetic subjects. Control of blood pressure appeared to improve with increasing municipality size among both hypertensive and diabetic subjects. HbAlc levels were below the recommended threshold in $30.5 \%$ of diabetic subjects indicating good glycemic control; no relation was found between glycemic control and municipality size. 
Table 1

Socio-demographic characteristics of hypertensive and diabetic subjects in the SERVIDIAH study, State of Pernambuco, Brazil, 2009 to 2010.

\begin{tabular}{|c|c|c|c|c|c|c|c|c|}
\hline & \multicolumn{4}{|c|}{ Hypertensive subjects } & \multicolumn{4}{|c|}{ Diabetic subjects } \\
\hline & $\begin{array}{l}\text { Large mu- } \\
\text { nicipalities } \\
(n=299)\end{array}$ & $\begin{array}{c}\text { Medium-sized } \\
\text { municipalities } \\
\text { (n=281) }\end{array}$ & $\begin{array}{l}\text { Small mu- } \\
\text { nicipalities } \\
(n=205)\end{array}$ & $\begin{array}{c}\text { All * } \\
(n=785)\end{array}$ & $\begin{array}{l}\text { Large mu- } \\
\text { nicipalities } \\
(n=319)\end{array}$ & $\begin{array}{l}\text { Medium-sized } \\
\text { municipalities } \\
\qquad(n=303)\end{array}$ & $\begin{array}{l}\text { Small mu- } \\
\text { nicipalities } \\
\text { (n= 201) }\end{array}$ & $\begin{array}{c}\text { All * } \\
(n=823)\end{array}$ \\
\hline Age (years) & $59.6 \pm 14.0$ & $60.5 \pm 13.7$ & $62.3 \pm 13.7$ & $60.5 \pm 13.9$ & $61.1 \pm 13.0$ & $61.0 \pm 13.4$ & $61.0 \pm 13.0$ & $61.1 \pm 13.2$ \\
\hline Male (\%) & 27.4 & 31.0 & 26.8 & 28.9 & 29.5 & 29.7 & 36.8 & 30.8 \\
\hline No formal schooling (\%) & 24.1 & 44.4 & 52.2 & 37.4 ** & 27.4 & 41.9 & 51.2 & $37.8^{* *}$ \\
\hline$<$ minimum wage $(\%)$ & 39.7 & 34.8 & 34.5 & 36.6 & 37.6 & 28.8 & 29.4 & $32.2^{\star \star \star}$ \\
\hline No formal employment (\%) & 75.8 & 82.2 & 82.7 & $79.8 * \star \star$ & 83.6 & 84.1 & 83.5 & 83.8 \\
\hline
\end{tabular}

* Weighted estimates to ensure representativeness for the whole state;

** $\mathrm{p}<0.001$ between municipality size;

$\star \star \star ~ p<0.05$ between municipality size.

Note: quantitative variables shown as mean \pm standard deviation.

Table 2

Clinical characteristics of hypertension and diabetes in subjects in the SERVIDIAH study, State of Pernambuco, Brazil, 2009 to 2010.

\begin{tabular}{|c|c|c|c|c|c|c|c|c|}
\hline & \multicolumn{4}{|c|}{ Hypertensive subjects } & \multicolumn{4}{|c|}{ Diabetic subjects } \\
\hline & $\begin{array}{l}\text { Large mu- } \\
\text { nicipalities } \\
(n=299)\end{array}$ & $\begin{array}{c}\text { Medium-sized } \\
\text { municipalities } \\
\quad(n=281)\end{array}$ & $\begin{array}{c}\text { Small mu- } \\
\text { nicipalities } \\
(n=205)\end{array}$ & $\begin{array}{c}\text { All * } \\
(n=785)\end{array}$ & $\begin{array}{l}\text { Large mu- } \\
\text { nicipalities } \\
(n=319)\end{array}$ & $\begin{array}{c}\text { Medium-sized } \\
\text { municipalities } \\
\quad(n=303)\end{array}$ & $\begin{array}{c}\text { Small mu- } \\
\text { nicipalities } \\
(n=201)\end{array}$ & $\begin{array}{c}\text { All * } \\
(n=823)\end{array}$ \\
\hline Duration (years) & $10.1 \pm 9.2$ & $9.8 \pm 9.0$ & $9.8 \pm 8.8$ & $9.9 \pm 9.0$ & $9.4 \pm 8.2$ & $8.5 \pm 7.2$ & $7.8 \pm 7.3$ & $8.7 \pm 7.6$ \\
\hline With hypertension (\%) & - & - & - & - & 81.0 & $73 . \%$ & 75.9 & 77.0 \\
\hline $\begin{array}{l}\text { Using anti-hypertensive } \\
\text { drugs (\%) }\end{array}$ & 94.6 & 90.6 & 86.3 & $91.4^{\star \star}$ & 94.9 & 91.0 & 94.7 & $93.2 * \star \star$ \\
\hline $\begin{array}{l}\text { Using only oral antidi- } \\
\text { abetic agents (\%) }\end{array}$ & - & - & - & - & 74.4 & 79.8 & 76.7 & 77.2 \\
\hline Using only insulin (\%) & - & - & - & - & 7.9 & 5.8 & 5.3 & 6.6 \\
\hline $\begin{array}{l}\text { Using insulin and oral } \\
\text { antidiabetic agents (\%) }\end{array}$ & - & - & - & - & 10.1 & 7.5 & 10.1 & 9.0 \\
\hline On weight-loss diet (\%) & 19.1 & 13.5 & 15.6 & 16.1 & 22.1 & 7.0 & 11.6 & $13.6 \#$ \\
\hline $\begin{array}{l}\text { Adhering to low-salt } \\
\text { diet (\%) }\end{array}$ & 86.2 & 87.9 & 93.2 & 88.1 \#\# & 83.9 & 88.7 & 96.7 & $88.1^{* \star *}, \#$ \\
\hline $\begin{array}{l}\text { Adhering to sugar-free } \\
\text { diet (\%) }\end{array}$ & - & - & - & - & 81.8 & 90.1 & 93.0 & $87.3 \#$ \\
\hline
\end{tabular}

* Weighted estimates to ensure representativeness for the whole state;

** $p<0.01$ between municipality size;

*** Only for diabetic subjects who declared hypertension;

\# $p<0.001$ between municipality size;

\#\# $p<0.05$ between municipality size.

Note: quantitative variables shown as mean \pm standard deviation.

The prevalence of overweight and obesity was extremely high in both samples $(74.7 \%$ in hypertensive subjects and $73.5 \%$ among diabetic subjects). BMI in hypertensive and diabetic subjects was $28.8 \pm 5.6$ and $28.4 \pm 5.3 \mathrm{~kg} / \mathrm{m}^{2}$ respectively. Approximately $70 \%$ of the total sample did not do any physical activity; the proportion of individuals not doing any physical activity appeared 
Clinical and metabolic control of blood pressure, blood glucose and of other cardiovascular risk factors in hypertensive and diabetic subjects in the SERVIDIAH study, State of Pernambuco, Brazil, 2009 to 2010.

\begin{tabular}{|c|c|c|c|c|c|c|c|c|}
\hline & \multicolumn{4}{|c|}{ Hypertensive subjects } & \multicolumn{4}{|c|}{ Diabetic subjects } \\
\hline & $\begin{array}{l}\text { Large munici- } \\
\text { palities } \\
\qquad(\mathrm{n}=299)\end{array}$ & $\begin{array}{c}\text { Medium-sized } \\
\text { municipalities } \\
\text { (n=281) }\end{array}$ & $\begin{array}{c}\text { Small munici- } \\
\text { palities } \\
(n=205)\end{array}$ & $\begin{array}{c}\text { All * } \\
(n=785)\end{array}$ & $\begin{array}{l}\text { Large munici- } \\
\text { palities } \\
\qquad(\mathrm{n}=319)\end{array}$ & $\begin{array}{l}\text { Medium-sized } \\
\text { municipalities } \\
\quad(n=303)\end{array}$ & $\begin{array}{l}\text { Small munici- } \\
\text { palities } \\
(n=201)\end{array}$ & $\begin{array}{c}\text { All * } \\
(n=823)\end{array}$ \\
\hline $\begin{array}{l}\text { Systolic blood pressure } \\
(\mathrm{mmHg})\end{array}$ & $139 \pm 21$ & $145 \pm 23$ & $147 \pm 20$ & $143 \pm 22$ ** & $138 \pm 23$ & $141 \pm 21$ & $144 \pm 22$ & $141 \pm 22^{\star \star \star}$ \\
\hline $\begin{array}{l}\text { Diastolic blood pressure } \\
(\mathrm{mmHg})\end{array}$ & $83 \pm 14$ & $86 \pm 14$ & $88 \pm 15$ & $85 \pm 14$ ** & $82 \pm 13$ & $84 \pm 13$ & $86 \pm 13$ & $83 \pm 13^{\star \star}$ \\
\hline $\begin{array}{l}\text { With well-controlled } \\
\text { blood pressure (\%) }\end{array}$ & 50.2 & 41.4 & 35.1 & $43.7 \%$ *** & 31.8 & 22.6 & 20.9 & $25.8^{\star \star \star}$ \\
\hline HbA1c levels (\%) & - & - & - & - & $8.6 \pm 2.3$ & $8.8 \pm 2.4$ & $8.8 \pm 2.5$ & $8.7 \pm 2.4$ \\
\hline $\begin{array}{l}\text { With well-controlled } \\
\text { HbA1c (\%) }\end{array}$ & - & - & - & - & 31.4 & 28.8 & 32.8 & 30.5 \\
\hline BMI (kg/m²) & $29.2 \pm 5.7$ & $28.8 \pm 5.9$ & $28.2 \pm 5.0$ & $28.8 \pm 5.6$ & $29.0 \pm 5.5$ & $28.0 \pm 5.4$ & $28.2 \pm 4.7$ & $28.4 \pm 5.3$ \\
\hline $\begin{array}{l}\text { Overweight [ } 25 \leq \mathrm{BMI} \\
<30 \text { ] (\%) }\end{array}$ & 35.8 & 35.6 & 36.2 & 35.8 & 37.5 & 40.0 & 44.6 & 39.4 \\
\hline Obese [BMI $\geq 30](\%)$ & 42.7 & 37.0 & 34.0 & 38.9 & 39.3 & 30.0 & 31.5 & 34.1 \\
\hline $\begin{array}{l}\text { With no physical activ- } \\
\text { ity (\%) }\end{array}$ & 63.8 & 73.0 & 71.2 & $69.1 \#$ & 63.9 & 76.0 & 71.9 & $70.6 \#$ \\
\hline Smokers (\%) & 13.0 & 12.2 & 15.1 & 13.0 & 14.4 & 12.5 & 10.9 & 13.0 \\
\hline
\end{tabular}

BMI: body mass index; Well-controlled blood glucose: HbA1c $<7 \%$; Well-controlled blood pressure: $<140 / 90 \mathrm{mmHg}$ in hypertensive subjects;

$<130 / 80 \mathrm{mmHg}$ in diabetic subjects.

* Weighted estimates to ensure representativeness for the whole state;

** $p<0.001$ between municipality size;

*** $p<0.01$ between municipality size;

\# $p<0.05$; between municipality size.

Note: quantitative variables shown as mean \pm standard deviation.

to be slightly lower in large municipalities (64\%) Smoking was reported by $13 \%$ of hypertensive and diabetic subjects.

\section{Discussion}

There is little research on the extent of risk factor control among hypertensive and diabetic patients in Brazil, whether at the primary care level or at more specialized levels. The SERVIDIAH study gives a picture of risk factor control at the primary care level in a representative sample of hypertensive and diabetic subjects registered with the FHS in the State of Pernambuco. As found by similar studies 11,12,13, the participants' income and education levels were generally low. The low rates of formal employment can be partly accounted for by the high mean age of the sample due to a high proportion of retirees and over-representation of women in the sample, many of which declared themselves housewives. Although common in studies at the primary care level $11,12,13,15,16,17,18,19$, the over-representation of women in this sample is contrary to expectations, since the prevalence of hypertension and diabetes does not differ greatly between men and women 14 . The greater number of women can be explained by the fact that overweight and obesity, prominent risk factors for both conditions, are generally more prevalent in women, especially those with low socio-economic status 20 . Another possible explanation is that women are known to use medical services more frequently than men 21 and therefore the under-representation of men may suggest the lack of an active search for male cases of hypertension and diabetes in the community.

The proportion of hypertensive subjects with blood pressure below 140-90mmHg found by our study $(43.7 \%$,) is somewhat higher than most other studies of samples in a primary care set- 
ting which observed rates of around $30 \% 11,18,22$. Only Sousa et al. 13 found a similar rate $(40.9 \%)$ in a study carried out in a small municipality in the South of Brazil. Nobre et al. 23 found a slightly higher proportion of patients with wellcontrolled hypertension (46.5\%) ; however, this study was conducted in specialized cardiological centers. The proportion of diabetics with blood pressure below the recommended threshold for type 2 diabetes was $25.8 \%$, showing that blood pressure control was much less satisfactory in diabetic subjects. We could not find other studies which investigated the extent of blood pressure control in diabetic subjects at primary care level. In a study of elderly subjects attending specialized centers, Silva et al. 24 found that $46 \%$ of type 2 diabetics had blood pressure below $130 / 85 \mathrm{mmHg}$. The findings of Gomes et al. 25 were similar to ours $(28.5 \%$ of subjects with systolic blood pressure below 130mmHg and 19.3\% with diastolic blood pressure below $90 \mathrm{mmHg}$ ). Outside Brazil, the few studies that have assessed blood pressure control by type 2 diabetic subjects show diverging results. In a sample of subjects attending general practices in Belgium, only $13 \%$ of the diabetic patients were found to have wellcontrolled blood pressure $(<130 / 80 \mathrm{mmHg}) 26$, whereas in the 1999-2000 US NHANES Study $35.8 \%$ of subjects achieved adequate blood pressure control 27 .

Blood glucose control in diabetic subjects from the SERVIDIAH study was unsatisfactory, since only $30.5 \%$ of subjects were found to have HbAlc levels below the $7 \%$ threshold. The proportion of diabetic patients with well-controlled glucose varies greatly from study to study. In a study of subjects attending a primary care health unit in São Paulo, Brazil, Silva 18 found that $42 \%$ of diabetic patients had HbAlc levels below the $6.5 \%$ threshold, which is similar to the rate found by a national survey of specialized centers $(46 \%$ of patients with HbAlc levels below the $7 \%$ threshold) 25 . On the other hand, another national survey of specialized centers found that only $27 \%$ of patients were below the $7 \%$ threshold 28 , and in a study of a sample attending a rehabilitation center, $24 \%$ of diabetic patients had HbAlc levels below $8 \% 24$. The results of studies outside Brazil vary greatly, ranging from a minimum of $16.7 \%$ of patients below the $7 \%$ threshold in a study of primary care units in Tunisia 29 , to a maximum of $55.7 \%$ in the $2003-2004$ US NHANES Study 30, with intermediate values observed by British 31 and French 32 studies and the above-mentioned Belgian study 26 of $24 \%, 40 \%$ and $49 \%$, respectively.

Since hypertensive and diabetic subjects are at very high risk of cardiovascular complica- tions, control of other cardiovascular risk factors should be an important part of healthcare. However, the SERVIDIAH study shows that control of other cardiovascular risk factors is less than satisfactory. The high prevalence of overweight and obesity is a general finding in most studies of hypertensive and/or type 2 diabetic patients $15,16,18,28,33$. It is also striking to note the low proportion of subjects that adhere to weight-loss diets ( $16.1 \%$ of hypertensive subjects and $13.6 \%$ of diabetic subjects). In a study of a sample of hypertensive and diabetic subjects from five municipalities located in the Baixada Santista in the South-east Region of Brazil, Bersusa et al. 34 found that more than $80 \%$ of subjects made no efforts to maintain or lose weight and that around $70 \%$ of subjects engaged in no leisure-time physical activity. This common finding in studies of this age group 11,34,35,36 highlights the need for protective measures against cardiovascular disease such as incentives to participate in community programs, such as the well-known Academia da Cidade program in Brazil 37, and the inclusion of physical educators and physiotherapists in primary care settings.

Diabetes control did not seem to be related to municipality size. However, control of blood pressure by both hypertensive and diabetic subjects improved with increasing municipality size. This may be related to other significant differences between large, medium-sized and small municipalities, such as education level, which is a factor known to influence health outcomes 38 . Also management of hypertension itself differed slightly between municipality size with greater use of antihypertensive medications by hypertensive subjects with increasing municipality size. Also, the proportion of subjects that adhered to weight-loss diets and were physically active was higher in large municipalities. On the other hand adherence to salt-free diets increased with decreasing municipality size. This may reflect a real difference in quality of care depending on municipality size, indicating a possible problem related to the decentralization of the health service where small municipalities find it more difficult to organize an adequate response to the health challenges facing their population 39,40 .

One of the main limitations of the SERVIDIAH study is the fact that much of data collection depended on declarations made by the subjects. Although the questionnaire was tested to ensure correct understanding of the questions and reliability of answers, the existence of biases or uncertainties cannot be discarded. The main strength of the study is that every effort was made to make the sample representative of hypertensive and diabetic users of the FHS in the state 
of Pernambuco, and the high response rate and absence of substitution of dropouts suggests that this was truly achieved.

In conclusion, this analysis of the SERVIDIAH database highlights a number of important aspects of the control of hypertension, diabetes and other cardiovascular risk factors in subjects attending the FHS in the State of Pernambuco. These include the following: the low proportion of men in the sample may reflect the fact that efforts to find male cases of hypertension and diabetes in the community were insufficient; on the whole, the results regarding control are comparable or similar to findings of other studies inside and outside Brazil in primary care or more specialized care settings, showing that control is unsatisfactory; extent of control may be influenced by municipality size. Further research is required to identify which elements of care have most impact on the control of risk factors and health status of hypertensive and diabetic patients attended by the FHS to help guide actions to improve patient care and prevent complications.

\section{Resumen}

El estudio SERVIDIAH (Evaluación de Servicios de Atención Básica a la Salud para Diabéticos e Hipertensos) fue realizado en 2010 en el estado de Pernambuco, Brasil. Se constituyó una muestra aleatoria de 785 hipertensos y 823 diabéticos, proveniente de los registros de 208 equipos de la Estrategia Salud de la Familia (ESF) en 35 municipios del estado. Los usuarios fueron entrevistados mediante un formulario padronizado, $y$ se les verificó el peso, altura y presión arterial y, a los diabéticos, la hemoglobina glicosilada (HbA1c). La edad media fue en torno a 60 años, con representación mayoritaria de mujeres (70\%). La presión arterial fue controlada en un 43,7\% de los hipertensos y un 25,8\% de los diabéticos; un 30,5\% de los diabéticos presentaron HbAlc por debajo de un 7\%. A pesar de que un $70 \%$ presentaron sobrepeso u obesidad, pocos informaron estar siguiendo una dieta para perder peso. El estudio, en esta muestra representativa de hipertensos y diabéticos registrados en la ESF de Pernambuco, muestra qué mejorías se deben buscar a fin de perfeccionar la prevención de las complicaciones de esos problemas, cuya incidencia está creciendo.

Hipertensión; Diabetes Mellitus; Programa de Salud Familiar; Factores de Riesgo

\section{Contributors}

A. Fontbonne, E. A. P. Cesse and E. F. Carvalho were responsible for study design, organized and supervised data collection, analysis and interpretation, and drafted this article. I. M. C. Sousa, A. F. B. Bezerra and V. L. V. Chaves contributed substantially to study conception, data collection, and interpretation of the results presented in this article, critically revised the paper for important intellectual content, and approved the final version of this article. W. V. Souza contributed substantially to study conception and statistical analysis, critically revised the paper for important intellectual content, and approved the final version of this article.

\section{Acknowledgments}

The authors wish to thank the institutions which funded the SERVIDIAH study, the administrators and technicians of the Family Health Strategy in the participating municipalities in the State of Pernambuco, the Public Health Residents and Master students and all personnel who contributed to data collection, data management and statistical analysis. We are also grateful to FACEPE, CNPq, Fiocruz and IRD for their financial support. 


\section{References}

1. Yach D, Kellogg M, Voute J. Chronic diseases: an increasing challenge in developing countries. Trans R Soc Trop Med Hyg 2005; 99:321-4.

2. Williams R, Van Gaal L, Lucioni C; CODE-2 Advisory Board. Assessing the impact of complications on the costs of type II diabetes. Diabetologia 2002; 45:S13-7.

3. Sociedade Brasileira de Cardiologia; Sociedade Brasileira de Hipertensão; Sociedade Brasileira de Nefrologia. VI diretrizes brasileiras de hipertensão. Arq Bras Cardiol 2010; 95 Suppl 1:1-51.

4. American Diabetes Association. Standards of medical care in diabetes 2011. Diabetes Care 2011; 34 Suppl 1:S11-61.

5. Bodenheimer T, Wagner EH, Grumbach K. Improving primary care for patients with chronic illness: the chronic care model, Part 2. JAMA 2002; 288:1909-14

6. Rothman AA, Wagner EH. Chronic illness management: what is the role of primary care? Ann Intern Med 2003; 138:256-61.

7. Secretaria de Políticas Públicas, Ministério da Saúde. Plano de reorganização da atenção à hipertensão arterial e ao diabetes mellitus. Rev Saúde Pública $2001 ; 35: 585-8$.

8. Rocha A, Soares R. Evaluating the impact of community-based health interventions: evidence from Brazil's Family Health Program. Health Econ 2010; 19:126-58.

9. Paim J, Travassos C, Almeida C, Bahia L, Macinko J. The Brazilian health system: history, advances, and challenges. Lancet 2011; 377:1778-97.

10. World Health Organization. Report of a WHO consultation on obesity: preventing and managing the global epidemic. Geneva: World Health Organization; 1998.

11. Santa Helena ET, Nemes MIB, Eluf-Neto J. Avaliação da assistência a pessoas com hipertensão arterial em unidades de Estratégia de Saúde da Família. Saúde Soc 2010; 19:614-26.

12. Paiva DCP, Bersusa AAS, Escuder MML. Avaliação da assistência ao paciente com diabetes e/ou hipertensão pelo Programa Saúde da Família do Município de Francisco Morato, São Paulo, Brasil. Cad Saúde Pública 2006; 22:377-85.

13. Sousa LB, Souza RKT, Scochi MJ. Hipertensão arterial e saúde da família: atenção aos portadores em município de pequeno porte na Região Sul do Brasil. Arq Bras Cardiol 2006; 87:496-503.

14. Sandberg K, Ji H. Sex differences in primary hypertension. Biol Sex Differ 2012; 3:7.

15. Borba TB, Muniz RM. Sobrepeso em idosos hipertensos e diabéticos cadastrados no Sistema HiperDia da unidade basica de saude do Simões Lopes, Pelotas, RS, Brasil. Journal of Nursing and Health 2011; 1:69-76.

16. Ferreira CLRA, Ferreira MG. Características epidemiológicas de pacientes diabéticos da rede pública de saúde - análise a partir do Sistema HiperDia. Arq Bras Endocrinol Metab 2009; 53:80-6.
17. Carlos PR, Palha PF, Veiga EV, Beccaria LM. Perfil de hipertensos em um núcleo de saúde da família. Arq Ciênc Saúde 2008; 15:176-81.

18. Silva RT. Controle de diabetes mellitus e hipertensão arterial com grupos de intervenção educacional e terapêutica em segmento ambulatorial de uma unidade básica de saúde. Saúde Soc 2006; 15:180-9.

19. Borges PCS, Caetano JC. Abandono do tratamento da hipertensão arterial sistêmica dos pacientes cadastrados no Hiperdia/MS em uma unidade de saúde do município de Florianópolis-SC. ACM Arq Catarin Med 2005; 34:45-50.

20. Monteiro CA, Moura EC, Conde WL, Popkin BM. Socioeconomic status and obesity in adult populations of developing countries: a review. Bull World Health Organ 2004; 82:940-6.

21. Figueiredo W. Assistência à saúde dos homens: um desafio para os serviços de atenção primária. Ciênc Saúde Coletiva 2005; 10:105-9.

22. Araújo JC, Guimarães AC. Controle da hipertensão arterial em uma unidade de saúde da família. Rev Saúde Pública 2007; 41:368-74.

23. Nobre F, Ribeiro AB, Mion Jr. D. Control de la presion arterial en pacientes bajo tratamiento antihipertensivo en Brasil - Controlar Brasil. Arq Bras Cardiol 2010; 94:645-52.

24. Silva RCP, Simões MJS, Leite AA. Fatores de risco para doenças cardiovasculares em idosos com diabetes mellitus tipo 2. Rev Ciênc Farm Básica Apl 2007; 28:113-21.

25. Gomes MB, Gianella D, Faria M, Tambascia M, Fonseca RM, Réa R, et al. Prevalence of type 2 diabetic patients within the targets of care guidelines in daily clinical practice: a multi-center study in Brazil. Rev Diabetic Stud 2006; 3:82-7.

26. Wens J, Gerard R, Vandenberghe H. Optimizing diabetes care regarding cardiovascular targets at general practice level: Direct@GP. Prim Care Diabetes 2011; 5:19-24.

27. Saydah SH, Fradkin J, Cowie CC. Poor control of risk factors for vascular disease among adults with previously diagnosed diabetes. JAMA 2004; 291:335-42.

28. Mendes ABV, Fittipaldi JAS, Neves RCS, Chacra AR, Moreira Jr. ED. Prevalence and correlates of inadequate glycaemic control: results from a nationwide survey in 6,671 adults with diabetes in Brazil. Acta Diabetol 2010; 47:137-45.

29. Ben Abdelaziz A, Soltane I, Gaha K, Thabet H, Tlili $\mathrm{H}$, Ghannem $\mathrm{H}$. Predictive factors of glycemic control in patients with type 2 diabetes mellitus in primary health care. Rev Epidemiol Santè Publique 2006; 54:443-52.

30. Hoerger TJ, Segel JE, Gregg EW, Saaddine JB. Is glycemic control improving in U.S. adults? Diabetes Care 2008; 31:81-6 
31. Fox KM, Gerber Pharmd RA, Bolinder B, Chen J, Kumar S. Prevalence of inadequate glycemic control among patients with type 2 diabetes in the United Kingdom general practice research database: a series of retrospective analyses of data from 1998 through 2002. Clin Ther 2006; 28:388-95.

32. Marant C, Romon I, Fosse S, Weill A, Simon D, Eschwège $\mathrm{E}$, et al. French medical practice in type 2 diabetes: the need for better control of cardiovascular risk factors. Diabetes Metab 2008; 34:38-45.

33. Gomes MB, Giannella Neto D, Mendonça E, Tambascia MA, Fonseca RM, Réa RR, et al. Prevalência de sobrepeso e obesidade em pacientes com diabetes mellitus do tipo 2 no Brasil: Estudo Multicêntrico Nacional. Arq Bras Endocrinol Metab 2006; 50:136-44.

34. Bersusa AAS, Pascalicchio AE, Pessoto UC, Escude MML. Acesso a serviços de saúde na Baixada Santista de pessoas portadoras de hipertensão arterial e/ou diabetes. Rev Bras Epidemiol 2010; 13:51322.

35. Alves JGB, Siqueira FV, Figueiroa JN, Facchini LA, Silveira DS, Piccini RX, et al. Prevalência de adultos e idosos insuficientemente ativos moradores em áreas de unidades básicas de saúde com e sem Programa Saúde da Família em Pernambuco, Brasil. Cad Saúde Pública 2010; 26:543-56.
36. Secretaria de Gestão Estratégica e Participativa Secretaria de Vigilância em Saúde, Ministério da Saúde. Vigitel Brasil 2010: vigilância de fatores de risco e proteção para doenças crônicas por inquérito telefônico. Brasília: Ministério da Saúde; 2011.

37. Simões EJ, Hallal P, Pratt M, Ramos L, Munk M, Damascena W, et al. Effects of a community-based, professionally supervised intervention on physical activity levels among residents of Recife, Brazil. Am J Public Health 2009; 99:68-75.

38. Cowell AJ. The relationship between education and health behavior: some empirical evidence. Health Econ 2006; 15:125-46.

39. Collins C, Green A. Decentralization and primary health care: some negative implications in developing countries. Int J Health Serv 1994; 24:459-75.

40. Atkinson S, Cohn A, Ducci ME, Fernandes L, Smyth F. Promotion and prevention within a decentralized framework: changing health care in Brazil and Chile. Int J Health Plann Manage 2008; 23:153-71.

Submitted on $10 /$ Sep/2012

Final version resubmitted on $03 / \mathrm{Jan} / 2013$

Approved on 31/Jan/2013 